Western University Scholarship@Western

Transition Economics Research Forum Reports (TERF)

1998

\title{
Capital Flight and Foreign Investment: Two Tales from China and Russia
}

Terry Sicular

Follow this and additional works at: https://ir.lib.uwo.ca/terf

Citation of this paper:

Sicular, Terry. "Capital Flight and Foreign Investment: Two Tales from China and Russia." Transition Economics Research Forum Reports (TERF), 1998-1. London, ON: Department of Economics, University of Western Ontario (1998). 
ISSN:0318-725X

ISBN:0-7714-2079-X

\title{
RESEARCH REPORT 9803 \\ (TERF REPORT 1998-1)
}

\section{Capital Flight And Foreign Investment: \\ Two Tales From China And Russia}

by

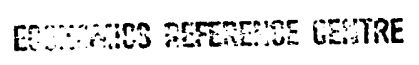

Terry Sicular MAR 251998

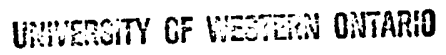

\author{
January 1998
}

\section{Transition Economics Research Forum}

Department of Economics Social Science Centre University of Western Ontario

London, Ontario, Canada

N6A 5C2

econref@sscl.uwo.ca 


\title{
CAPITAL FLIGHT AND FOREIGN INVESTMENT: TWO TALES FROM CHINA AND RUSSIA ${ }^{*}$
}

\author{
Terry Sicular \\ Department of Economics \\ University of Western Ontario \\ London, Ontario N6A 5C2 \\ Canada
}

First Draft: October 1997

This revision: January 1998

II would like to thank Academician Abalkin and our Russian colleagues for their very helpful comments. Support from the Gorbachev Foundation and the University of Western Ontario's Academic Development Fund is gratefully acknowledged. 


\section{INTRODUCTION}

In recent years both Russia and China have experienced capital flight, reportedly on a large scale. In the case of Russia, capital flight has been accompanied by slow growth of inflows of foreign investment. In contrast, China has experienced rapid growth in foreign investment. The differing experiences of Russia and China raise questions about the nature of capital flight in the two countries and about the relationship between capital flight outflows and foreign capital inflows.

The Russian experience seems easier to explain, as foreign and domestic investors are behaving in similar ways: neither group seems keen to invest in the Russian economy. This consistency of behaviour can be explained by the overall investment climate. If the returns to investment are low and risk is relatively high due to economic, political, legal, or regulatory factors, then both foreign and domestic investors will seek to take their savings elsewhere. Under such circumstances efforts to stem capital flight should focus on improving the overall climate for investment, with positive consequences for investment both by residents and foreigners.

Yet the Chinese experience suggests that even in a setting where the economy is experiencing dynamic growth and attracting foreign investors, residents may seek to send their savings abroad. Why is this so? The different behaviour of foreign and domestic investors arises because they face different incentives or receive different returns. In China a variety of factors cause differential returns between foreign and domestic investors. Some of these factors arise because of China's socialist economic legacy. Thus comparison of China and Russia can yield useful insights.

Examining relationships between capital flight and inflows of foreign investment in China and Russia raises further questions. Do inflows of foreign investment facilitate capital flight by 
increasing the availability of foreign exchange? To what extent are observed inflows of foreign investment financed by savings of foreign origin versus the return or recycling of fled capital? In this paper I explore some such issues. I begin below with a brief discussion of definitions and an evaluation of available statistics.

\section{DEFINITIONS}

The literature contains a range of definitions for capital flight. Many authors view capital flight as a subset of total capital outflows from a country. Some view capital flight as "abnormal" flows of capital driven by fears and uncertainty, or motivated by the desire to hide or launder abroad money earned illegally through criminal activity or corruption. Kindleberger (1937), for example, defines capital flight as abnormal outflows of capital propelled by "fears and suspicions." His definition focuses on capital flows that are liquid and relatively volatile.

Other authors argue that the concept of "capital flight" as a distinct category is misleading, and that from an analytical perspective one should simply look at all outflows of productive resources (e.g., Tornell and Velasco, 1992). This definition is broader and includes both long and short-term capital outflows. ${ }^{1}$ For both practical and analytical reasons, I am inclined to favour this broader definition. Measurement is more difficult for narrower than for broad definitions, in part because illegal flows are hidden and in part because of possible disagreement over what to include and what to exclude. Furthermore, the word "abnormal" is vague and lacks clear economic content.

Narrower and broader definitions are also possible for foreign investment. Since this paper focuses on incentives facing profit-seeking investors, an appropriate definition of foreign investment would include all investment inflows from private individuals and profit-seeking

${ }^{1}$ For a more in-depth discussion of definitions and measures of capital flight, see Kant (1996), pp. 5-10. 
organizations, be they in the form of direct investment or portfolio investments. By this definition, foreign investment would include both long-term investments in enterprises and more liquid investments in stocks, bonds, etc., but would exclude loans from governments and international organizations.

Despite my preference for broader definitions of capital flight and foreign investment, the discussion below at times returns to narrower definitions. In part this is due to data limitations: statistics on capital flight and foreign investment for China and Russia are of uneven quality and availability. I therefore present a range of estimates in the hope that even if individual estimates are off the mark, as a group they give a picture of where the target is located.

\section{LEVELS OF FOREIGN CAPITAL INFLOWS AND CAPITAL FLIGHT FOR CHINA AND RUSSIA}

Data for China appear in tables 1 and 2. Since 1990 China has experienced unprecedented growth in inflows of foreign capital (table 1). Data are most complete for net and gross FDI, both of which grew steadily from less than $\$ 1.5$ billion² in the early 1980 s to more than $\$ 35$ billion by 1995. ${ }^{3}$ This growth accelerated noticeably in 1991: FDI (both net and gross) more than doubled in absolute value in 1992 and again in 1993. Thereafter growth settled down to rates of 10 to 20 percent annually. Thus between 1991 and 1995 FDI inflows had increased ten fold.

Broader measures of foreign investment inflows are available only starting in 1990, but they follow a similar pattern of growth. Net inflows of private capital increased five fold between 1990 and 1995. The movement in total net inflows appears to have been driven largely by trends in FDI,

\footnotetext{
${ }^{2}$ All dollar amounts are in U.S. dollars.

${ }^{3}$ The figures cited here are for actual FDI as opposed to contracted amounts.
} 
its largest component. Portfolio inflows have been less dynamic than FDI. China only began to allow foreign sales of equities by domestic companies in 1992, at which time it established trading for B shares (priced in domestic currency but purchased with hard currencies) on the Shanghai and Shenzhen stock markets. Also in 1992 the Chinese Securities Regulatory Commission began to allow Chinese companies to list and sell shares on foreign markets (Lardy, 1995, pp. 1069-1070). Statistics on proceeds from international sales of Chinese equities and debt instruments show total sales increasing from less than $\$ 130$ million in 1991 to more than $\$ 5$ billion in 1994, and then levelling off. Net portfolio equity flows show similar trends. (See table 1.) These amounts are dwarfed by the numbers for FDI, but they are still substantial.

Capital flight estimates for China are available in a recent study by Gunter (1996). Gunter uses two basic approaches to estimation. The first, the "balance of payments method," estimates capital flight as the sum of reported short-term capital exports by the nonbank sector plus errors and omissions. Errors and omissions are thought to capture unrecorded short-term capital flows (Cuddington, 1986). This method defines capital flight narrowly to include only short-term flows or "hot" money.

The second approach calculates capital flight as a residual between actual foreign borrowing and necessary foreign borrowing as implied by the current account balance. Estimated capital flight equals the difference between actual foreign borrowing and the sum of the current account balance, changes in reserves, and net foreign direct investment. This second approach is broader and more widely accepted than the first, and so while table 2 gives both estimates, I will refer primarily to the broader estimates calculated using the residual approach.

Gunter's estimates of capital flight using the residual approach (unadjusted) show capital flight fluctuating between zero (actually, slightly negative in one year) and $\$ 8$ billion in the mid- 
and late 1980s, then stepping up to levels of $\$ 10-25$ billion in the early 1990 s (table 2). He gives two sets of "adjusted" estimates, one lower and one higher, both of which show the same jump in the 1990s. Estimates calculated using the "balance of payments method" also show a substantial step upward in the early 1990s. These figures suggest that China in the early 1990 s experienced large concurrent increases in both capital flight and foreign investment.

Statistics for Russia are less complete than for China, but they allow a rough comparison. Statistics for foreign investment taken from World Bank publications are shown in table 3 . In the early 1990s net private capital inflows to Russia fluctuated between $\$ 200$ million and $\$ 10.8$ billion, with no clear trend over time (although preliminary figures for 1996 show signs of growth). Most capital inflows appear to have been in the form of foreign direct investment rather than portfolio investments, which remained small until 1996.

Estimates of capital flight for Russia vary widely. Most estimates are calculated by directly estimating the different components of capital flight, rather than indirectly using balance of payments statistics. For Russia the indirect approach is problematic because the balance of payments statistics are unreliable. Especially during the early 1990s, Russia's trade statistics did not fully reflect trade between Russia and other former Soviet republics, which transactions were probably substantial.

While estimates of capital flight from Russia differ, they generally seem to fall in the range of $\$ 10$ to $\$ 25$ billion annually. One set of estimates by Illarionov (cited by Loukine, 1997) gives capital flight of $\$ 14$ billion in 1992, \$11 billion in 1993 and in 1994, and \$7 billion in 1995. ${ }^{4}$ A second set of estimates by Sarafanov (1995) puts capital flight at $\$ 24.1$ billion in 1992 and $\$ 21.7$ billion in

\footnotetext{
${ }^{t}$ The methodology used by Illarionov to calculate capital flight is unknown.
} 
1993. ${ }^{5}$

These estimates suggest that capital flight from Russia has been more or less in the same range as that for China, with Russian capital flight perhaps lower than China's. China and Russia differ noticeably, however, in the levels of foreign capital inflows. Net inflows of foreign capital have been much smaller for Russia than for China.

\section{CAPITAL FLOWS RELATIVE TO DOMESTIC ECONOMIC ACTIVITY}

Comparing foreign capital inflows and capital flight to each country's GNP and levels of savings and investment puts these figures in perspective. Since the late 1980s China's GNP has been rising, while Russia's has been falling. China's GNP in 1988 was $\$ 307$ billion, rising to $\$ 686$ billion in 1995; Russia's fell from $\$ 556$ billion to $\$ 320$ billion over the same period (World Bank, 1997b, pp. 152, 440). ${ }^{6}$ Similarly, levels of savings and investment as a share of national product have been rising in China, while they have fallen in Russia (table 4). These macroeconomic statistics, especially those for Russia, are debatable, but they are consistent with accepted trends in the two countries.

Relative to GNP, inflows of foreign capital to China remained small until the 1990s. Prior to 1991 net inflows of private capital were about $2 \%$, and net FDI about 1\%, of GDP. This compares to total investment rates exceeding 35\%. After 1991 both net private capital flows and FDI rose to more than $5 \%$ of GNP. The total investment rate also rose, but even so the relative importance of foreign capital in domestic investment increased: by the mid-1990s foreign capital appears to have

\footnotetext{
5Sarafanov's estimates include both short- and long-term flows and estimated mis-invoicing, so they are roughly comparable to Gunter's higher estimates for China using the residual approach. The numbers given here are Sarafanov's estimates of illegal plus legal capital outflows. Illegal capital inflows are not subtracted.

${ }^{6}$ These figures are converted to US dollars using official exchange rates.
} 
contributed roughly $15 \%$ of total investment. In Russia, by comparison, inflows of foreign capital have in most years remained well below 5 percent of GNP and are small relative to total investment. (See table 4.)

Capital flight from China has increased relative to GNP. Gunter's unadjusted residual estimate rises from about $1 \%$ of GNP in the late 1980 s to $4-5 \%$ in the mid-1990s; the high, adjusted residual estimate rises from about $5 \%$ of GNP in $1988 / 89$ to over $12 \%$ in $1993 / 94$. $^{7}$ Thus, by the mid-1990s capital flight was equivalent to between 12 and $27 \%$ of domestic savings. These numbers suggest that a substantial portion of domestic savings was finding its way out of the country.

Available statistics suggest that capital flight from Russia has been somewhat smaller relative to the size of the economy. Estimates suggest that capital flight has remained below 6 percent of GNP. Due to Russia's lower savings rate, capital flight still accounts for a substantial portion of its domestic savings--between 8 and 18 percent. These numbers, however, are lower than those for China.

\section{THE OVERALL INVESTMENT CLIMATE}

Explanations for capital flight usually focus either on the country's overall investment climate, regardless of who is investing, or on differences between residents and nonresidents in returns to and risks in investment. Foreign investment is thought to respond to the same factors-the investment climate and policies that provide special incentives to foreign investors (Kant, 1996, pp. 1-2). The overall investment climates of China and Russia have differed markedly.

\footnotetext{
${ }^{7}$ I would favor either the unadjusted or high, adjusted residual estimates (the low estimates exclude reported capital outflows through the banking system, which in my view should be included).
} 
Macroeconomic performance in Russia has been weak, characterized by slow growth in GNP, weak domestic demand, and high inflation. In contrast, China has experienced sustained, rapid growth in GNP. This growth, together with rising household incomes and relatively stable prices and exchange rates have made China an attractive target for both foreign and domestic investors.

Inflation and the exchange rate can influence relative returns to investing within versus outside a country. While China has experienced inflationary episodes during its reform period, the peak rates of inflation have been lower than in Russia. Moreover, during each episode the central government quickly took effective steps to reduce inflation to low or moderate levels. The Chinese yuan has depreciated substantially since the early 1980s, but the exchange rate has been fairly stable since 1990 and depreciation has been relatively gradual and predictable in comparison to the Russian experience during the same period.

Despite political uncertainty following the Tiananmen Incident and the recent leadership transition following Deng Xiaoping's death in early 1997, to date China has maintained political stability and continuity in its economic reform program. This, combined with China's rapid economic growth, have contributed to China's assessment as a relatively low-risk investment environment. The Economist Intelligence Unit, a risk assessment organization, gave China a risk rating of 15 (100 is the highest risk) in 1988, one of its lowest ratings. This rating rose to 35 in 1989 after the Tiananmen Incident, but then fell in the early 1990s and then ranged between 25 and 35. This rating put China seventeenth from the top in terms of country risk in 1994, behind countries such as Mexico, India, Greece and Indonesia. In contrast, Russia's country-risk rating in 1994 was 90, the second highest level of risk after Iraq ('Emerging-Market Indicators', 1994, p. 120).

In addition to the above macroeconomic and political factors, structural change in China's economy has also contributed to its attractiveness to investors. China's economic growth since 1980 
has largely been driven by expansion of production and investment outside of the traditional stateowned industrial sector. Growth has been most rapid in township and village enterprises (TVEs). TVEs are sometimes private, but usually are collective or quasi-public enterprises set up with funding and support from local village and township governments. By 1996 TVEs accounted for one-quarter of China's GDP, $44 \%$ of China's value-added in industry, and $35 \%$ of China's export earnings ("Rural industries ...," 1997).

In the context of this discussion, China's TVE sector is significant because it has become a key destination for both domestic and foreign investment. Enterprises in this sector are favoured by investors because they yield higher, faster returns than the state sector. TVEs are subject to less regulation, can hire (and fire) labour more freely, pay lower wages, and have more flexibility. In contrast, the economic performance of state-owned enterprises has been weak with many lossmaking firms. State enterprises are subject to stricter regulation and oversight, and they operate in a climate of substantial uncertainty because of ongoing debates within the government regarding how to reform the state enterprise sector. The potential for major policy changes that could drastically reduce subsidies, allow widespread bankruptcies, and restructure ownership in this sector has been high. ${ }^{s}$ TVEs are more attractive to investors not only than state enterprises, but also than private businesses, because the wholly private sector still occupies a relatively marginal position in the economy, and investments in private enterprises do not enjoy the same level of official protection and support as TVEs.

Russia's economy contains a large state-owned enterprise sector and a private sector, but it lacks an equivalent to China's TVE sector. Foreign and domestic investors in Russia thus must

\footnotetext{
${ }^{8}$ Indeed, developments in 1997-98 suggest that the Chinese government has begun to adopt such policies in a serious fashion (Central Intelligence Agency, 1997).
} 
choose between investment in the problematic state sector and in the incipient private sector, with no intermediate option. The absence of such an intermediate sector is perhaps due to government policies during the transition, differences in labour supply conditions (China has large underemployed labour resources, mostly in rural areas), or perhaps is historical in origin. In the late 1950s China carried out an administrative decentralization, shifting from vertical planning through ministries to horizontal planning through regional and local governments, and began to stress rural self-sufficiency and the development or rural industries (the "walking on two legs" policy). The Soviet Union did not follow such a path. Kruschev attempted but failed to carry out administrative decentralization in the 1960s, and the USSR continued its long-standing program of industrial specialization and concentration.

\section{DIFFERENCES IN RETURNS AND RISKS TO INVESTMENT BETWEEN NON-RESIDENTS AND RESIDENTS}

Government policies favouring foreign investment often cause the returns and risks to investment by foreigners to differ from those for domestic investors. Such policies have been common in China. Central and local governments have adopted a range of special provisions to attract foreign investment, including tax concessions, liberalized land leasing options, government guarantees on loans by foreign lenders to domestic borrowers, and special arrangements regarding the retention and repatriation of foreign exchange. Such provisions have apparently been effective in creating higher returns to foreign capital, as there is evidence that they cause Chinese investors to move money offshore and then bring it back into the country disguised as foreign investment. The amount of such recycled funds could be quite large: a recent World Bank report guesses that recycled funds could account for as much as $25 \%$ of gross foreign investment China in 1992 (Lardy, 
1995, p. 1067; Peter Harrold and Rajiv Lall, 1993, p. 24).

Yet differences in returns and risks can also occur for other reasons. If the choice to invest in a country depends on the impact of that investment on the overall return and risk of the investor's portfolio, then the incentive to invest will differ if foreigners and residents face different opportunities for diversification. This portfolio effect is relevant for both China and Russia, where residents face limited opportunities to diversify.

In the case of China, dynamic economic growth has led to increased incomes, and higher incomes have generated significant growth in domestic savings. Incomes have risen at annual rates of 8 to $10 \%$, and the rate of savings has been high and rising over time. Domestic savings rates in China have increased from $28 \%$ of GDP in 1980 to over $40 \%$ in the early 1990 s (table 4 and World Bank, 1994).

While savings have grown dramatically, the choice of domestic instruments for saving and investment have remained limited (especially for individuals and households, but also for institutions). Until recently, bank deposits and government bonds were the only ideologically acceptable and thus available savings options (aside from holding cash or commodities, or selfinvestment, discussed below). These instruments still remain more accessible and common then most other savings instruments. They offer relatively safe but low returns. Interest rates are set by the government. While the rates are sometimes indexed, in general they do not provide full protection against domestic inflation, let alone against exchange rate fluctuations.

Holdings of commodities have reportedly increased in China, especially during inflationary episodes. Precious metals, especially gold, have been popular as an alternative form of savings that is immune to inflation and foreign exchange risks, although gold prices on international markets have fallen substantially. In rural areas farm households appear to hedge against inflation by 
holding stocks of grain and livestock, with negative consequences for price stability in these markets (see Johnson and Song, 1995).

Despite steps toward liberalization, markets for real estate, insurance, and capital remain relatively underdeveloped. The insurance industry has been monopolized by the state and is backwards. Pension funds have only recently been set up on an experimental basis. Land markets are incipient. Although cities are carrying out reforms allowing individuals to buy their residences, rights to sell or transfer property are still limited. Progress in the development of commercial real estate markets is also slow. Thus Chinese residents for the most part lack easy access to real estate investments, which constitute an important portfolio choice elsewhere.

Equity markets in China remain relatively small in size, are subject to discretionary administrative interventions by the government, and operate in a weak legal and regulatory environment. They are also fragmented regionally and are highly volatile (Johnson, 1997, p. B4). Investment in business enterprises is thus dominated by self-investment where firms reinvest their earnings internally and individuals invest their savings in their own private businesses or in the enterprises in which they are employed or have a collective interest.

In the face of such limited options, Chinese investors have an incentive to transfer savings offshore so as to achieve a more balanced portfolio. Offshore investments also offer protection against domestic inflation and exchange rate depreciation. Some observers have noted that the astronomical growth in Hong Kong real estate prices during the 1980s and early 1990s has been driven by inflows of funds from the Mainland. While the statistics in table 4 show that the majority of Chinese savings continues to be invested domestically, rising capital outflows suggest that Chinese investors are increasingly diversifying through both visible and hidden channels into offshore investments. 
China's lack of savings instruments reflects its socialist legacy. Russia and China share similar backgrounds in this regard, and so it is not surprising that investors in Russia face a similar lack of savings portfolio options. The situation for Russian savers is in fact worse than for Chinese savers because of hyperinflation and dramatic currency devaluation. Furthermore, moves to deregulate the banking industry in Russia have led to the establishment of banks with uncertain financial prospects, and there have been cases of bank failures. Such conditions create a motivation for capital flight that would probably persist even if Russia's overall investment climate improved.

The main point here is that portfolio considerations create different returns and risks for resident versus nonresident investors. Nonresident investors holding diversified international portfolios may find that, on the margin, investing in China or Russia will improve the returns relative to risks in their portfolios. This is less likely to hold for residents.

\section{CONCLUSIONS}

The issue of capital flight has received considerable attention in Russia, more so than in China. Yet the magnitude of capital flight from China relative to both GDP and levels of domestic investment and saving appears to be noticeably higher than that for Russia. This raises the question of why capital flight has been a "hot" issue in one country but not the other. One explanation may be that where foreign capital inflows are large and growing, as in China, capital outflows cause less concern. Net inflows of foreign capital to Russia, in contrast, have remained small with only weak signs of sustained growth.

Other explanations could be tied to social and political factors. In Russia the beneficiaries from capital flight may comprise a smaller segment of society, or capital flight may be more closely linked to illegal activities than it is in China. The Russian press is freer than China's, so that politically sensitive topics receive more, and at times sensationalized, coverage. In Russia capital flight has been an issue over which political battle lines have been publicly drawn; in China public 
political debates are more proscribed, and political battles occur behind closed doors. Closer reading of the Chinese press, moreover, suggests that the "hot" issue in China is not capital flight, but the broader problem of corruption.

Comparison of China and Russia yields several lessons. First, it provides perspective on the magnitude of the problem of capital flight. The estimates for Russia's capital flight and GNP given in the tables are debatable, but they suggest that relative to other macroeconomic indicators and relative to the case of China, Russian capital flight is not so large. Second, comparison of China and Russia suggests that one reason for China's attractiveness to investors is the presence of an intermediate sector between the state-owned and private sectors. Both countries have large state sectors, but these sectors have had weak profit performance and, for reasons discussed above, are problematic for investors. Both countries also have small private sectors, but the private sectors operate in an unpredictable regulatory and market settings and lack the strong official backing that can be essential to success in a transition economy. Investors have a third alternative in China, the TVE sector. In the short and medium run, TVEs have provided an option that is attractive to both resident and nonresident investors. While Russia may lack the initial conditions for a TVE sector resembling China's, there may be other routes for developing an alternative sector for investors.

Third, China's experience reveals that improving the overall investment climate may be a necessary condition for stemming capital flight, but it is not sufficient. Capital flight will persist if, due to discriminatory policies or limited portfolio options, residents can achieve higher returns at lower levels of risk on their investment portfolio by investing abroad. Indeed, so long as such conditions persist, growth in GDP and personal incomes would likely lead to even greater capital flight, as domestic savings will increase and so residents will wish to transfer yet more capital overseas. Efforts to reduce capital flight must therefore reduce the differential between returns to domestic and foreign investors, and must take steps to develop a wider range of domestic savings mechanisms in areas such as real estate, insurance, commodities, equity, and bonds. 


\section{REFERENCES}

Central Intelligence Agency (1997), China's Economy in 1995-97, APLA 97-10008, December. 'China's Rural:Industries Continue 15-percent Growth' (1997), China News Digest GL97-138. October 8.

Cuddington, John T. (1986), 'Capital Flight: Estimates, Issues, and Explanations,' Princeton Studies in International Finance, 58.

Cuddington, John T. (1987), 'Capital Flight', European Economic Review 31: 382-388.

'Emerging-Market Indicators',(1994), The Economist, 331(7864), May 21: 120.

Gunter, Frank R. (1996), 'Capital Flight from the People's Republic of China, 1984-1994', China Economic Review, 7(1): 77-96.

Harrold, Peter and Rajiv Lall (1993), 'China: Reform and Development in 1992-93' (Washington, DC: World Bank Discussion Paper 215).

International Monetary Fund (1994), International Capital Markets: Developments, Prospects and Policy Issues (Washington, DC: International Monetary Fund).

International Monetary Fund (1996), International Financial Statistics Yearbook, 1996. Vol. XLIX.

Johnson, D. Gale and Guoqing Song (1995), 'Inflation and the Real Price of Grain in China'. Paper prepared for the Conference on Grain Market Reform in China, East-West Center, Honolulu.

Johnson, Ian (1997), 'Chinese Trades Rock Commodity Markets', The Globe and Mail. August 25, 1997: B4.

Kant, Chander (1996), 'Foreign Direct Investment and Capital Flight', Princeton Studies in International Finance, 80. 
Kindleberger, Charles P. (1937), International Short-Term Capital Movements (New York: Augustus Kelley).

Lardy, Nicholas (1995), 'The Role of Foreign Trade and Investment in China's Economic Transformation', The China Quarterly, 144: 1065-1082.

Loukine, Konstantin (1997), 'Capital Flight from Russia as Reported in the Russian Press'. (London, Ont.: University of Western Ontario, unpublished manuscript).

Sarafanov, Michail (1995), 'Russia's Actual and Potential Role in International Capital Flows', in Janos Gacs and Merton J. Peck (eds.), International Trade Issues of the Russian Federation. IIASA Collaborative Papers CP-95-2. April: 239-249.

State Statistical Bureau (1996), China Statistical Yearbook 1996 (Beijing: China Statistical Publishing House).

Tornell, Aaron and Andres Velasco (1992), "The Tragedy of the Commons and Economic Growth: Why Does Capital Flow from Poor to Rich Countries?', Journal of Political Economy, 100: 1208-1231.

World Bank (1994), China: Macroeconomic Stability in a Decentralized Economy (Washington, DC: The World Bank).

World Bank (1997a), Global Development Finance, 1997, Volume I (Washington, DC: World Bank).

World Bank (1997b), Global Development Finance, 1997, Volume II (Washington, DC: World Bank). 
Table 1

Foreign Investment in China

(million US dollars)

\begin{tabular}{|c|c|c|c|c|c|c|}
\hline \multirow[t]{2}{*}{ Year } & \multirow{2}{*}{$\begin{array}{l}\text { Net Private } \\
\text { Capital Flows }\end{array}$} & \multicolumn{2}{|c|}{ Foreign Direct Investment } & \multicolumn{2}{|c|}{$\begin{array}{c}\text { International } \\
\text { Issues }\end{array}$} & \multirow{2}{*}{$\begin{array}{l}\text { Net Portfolio } \\
\text { Equity Flows }\end{array}$} \\
\hline & & Net & Gross & Equity & Bonds & \\
\hline 1984 & & 1258 & 1419 & & & \\
\hline 1985 & & 1659 & 1959 & & & \\
\hline 1986 & & 1875 & 2244 & & & \\
\hline 1987 & & 2314 & 2647 & & & \\
\hline 1988 & & 3194 & 3739 & & & 0 \\
\hline 1989 & & 3393 & 3773 & & & 0 \\
\hline 1990 & 8100 & 3487 & 3755 & & & 0 \\
\hline 1991 & 7500 & 4366 & 4666 & 11 & 115 & 653 \\
\hline 1992 & 21300 & 11156 & 11291 & 1049 & 1289 & 1194 \\
\hline 1993 & 39600 & 27515 & 27771 & 1800 & 3184 & 3818 \\
\hline 1994 & 44400 & 33787 & 33946 & 2803 & 3602 & 3915 \\
\hline 1995 & 44300 & 35849 & 37806 & 666 & 1611 & 2807 \\
\hline 1996 & $52000^{\circ}$ & $42300^{\circ}$ & 37806 & $1369^{\circ}$ & $3783^{\circ}$ & \\
\hline
\end{tabular}

Preliminary.

Note: Data are not available for all years. These figures are capital and investments by nonresidents. "Net" indicates that disinvestment, repatriated profits, dividends, interest and amortization are subtracted; these figures are not "net" of investment abroad by residents.

Sources:

Net private capital flows: World Bank, 1997a, p. 7.

Net foreign direct investment: International Monetary Fund, 1996, p. 281, and World Bank, 1997a, p. 29 and 1997b, p. 152.

Gross foreign direct investment: State Statistical Bureau, 1996, p. 597.

International equity and bond issues: World Bank, 1997a, pp. 111, 113, and Lardy, 1995, p. 1070.

Net portfolio equity flows: World Bank, 1997b, p. 152. 
Table 2

Estimates of Capital Flight for China

(million US dollars)

\begin{tabular}{ccccccc}
\hline & \multicolumn{3}{c}{ Residual Method } & \multicolumn{2}{c}{ Balance of Payments Method } \\
\cline { 2 - 6 } Year & Unadjusted & $\begin{array}{c}\text { Adjusted, } \\
\text { Low }\end{array}$ & $\begin{array}{c}\text { Unadjusted, } \\
\text { High }\end{array}$ & Unadjusted & $\begin{array}{c}\text { Adjusted, } \\
\text { Low }\end{array}$ & $\begin{array}{c}\text { Adjusted, } \\
\text { High }\end{array}$ \\
\hline 1984 & 4247 & 3465 & 6737 & 1775 & 993 & 4265 \\
1985 & -1021 & 809 & 6406 & 310 & 2140 & 5368 \\
1986 & 3436 & 6061 & 10842 & -209 & 1585 & 6539 \\
1987 & 8767 & 5124 & 16868 & 1493 & 1722 & 10165 \\
1988 & 3264 & -1181 & 17319 & 1598 & -985 & 13598 \\
1989 & 1234 & 3496 & 20734 & 869 & 427 & 20554 \\
1990 & 10288 & 2704 & 38432 & 8482 & 6927 & 31241 \\
1991 & 8942 & 3482 & 41127 & -337 & -2329 & 29691 \\
1992 & 24571 & 17590 & 63253 & 11698 & 9314 & 48307 \\
1993 & 23562 & 9408 & 56167 & 12369 & -1541 & 44646 \\
1994 & 22000 & 15000 & 66000 & 19000 & 8000 & 63000 \\
\hline
\end{tabular}

Notes:

1. Residual method: Sum of the current account balance, net foreign investment, change in reserves, and change in foreign debt. The low adjusted estimate adds in an estimate of capital flight through mis-invoicing between the PRC including Hong Kong and the rest of the world, and subtracts changes in non-reserve foreign assets of the PRC banking system (which represent "legitimate" foreign assets). The high adjusted estimate adds in estimated mis-invoicing between the PRC excluding Hong Kong and the rest of the world plus a bank debt adjustment to correct for gaps in the Chinese foreign debt statistics.

2. Balance of payments method: Sum of nonbank private short-term capital flows and net errors and omissions. The low adjusted estimate adds in an estimate of mis-invoicing between the PRC including Hong Kong and the rest of the world. The high adjusted estimate adds in estimated misinvoicing between the PRC excluding Hong Kong and the rest of the world.

Source: Gunter, 1996, p. 79. 
Table 3

Foreign Investment in Russia

(million US dollars)

\begin{tabular}{|c|c|c|c|c|c|}
\hline \multirow{2}{*}{ Year } & \multirow{2}{*}{$\begin{array}{c}\text { Net Private } \\
\text { Capital Flows }\end{array}$} & \multirow{2}{*}{$\begin{array}{c}\text { Net Foreign } \\
\text { Direct } \\
\text { Investment }\end{array}$} & \multicolumn{2}{|c|}{ International Issues of } & \multirow[b]{2}{*}{$\begin{array}{l}\text { Net Portfolio } \\
\text { Equity Flows }\end{array}$} \\
\hline & & & Equity & Bonds & \\
\hline 1988 & & 0 & & & 0 \\
\hline 1989 & & 0 & & & 0 \\
\hline 1990 & 5600 & 0 & & & 0 \\
\hline 1991 & 200 & 0 & & & 0 \\
\hline 1992 & 10800 & 700 & & & 0 \\
\hline 1993 & 3100 & 700 & 0 & 0 & 0 \\
\hline 1994 & 300 & 637 & 5 & 0 & 271 \\
\hline 1995 & 1100 & 2017 & 23 & 347 & 141 \\
\hline 1996 & $3600^{\circ}$ & & $808^{\circ}$ & $1100^{\circ}$ & \\
\hline
\end{tabular}

Preliminary.

Note: Data are not available for all years. These figures are capital and investments by nonresidents. "Net" indicates that disinvestment, repatriated profits, dividends, interest and amortization are subtracted; these figures are not "net" of investment abroad by residents.

Sources:

Net private capital flows: World Bank, 1997a, p. 7.

Net foreign direct investment: World Bank, 1997b, p. 440.

International equity and bond issues: World Bank, 1997a, pp. 111, 113.

Net portfolio equity flows: World Bank, 1997b, p. 440. 
Table 4

Savings, Investment, Foreign Capital Flows and Capital Flight Relative to National Product (percentages of national product)

\begin{tabular}{|c|c|c|c|c|c|c|c|c|c|c|}
\hline \multirow[b]{2}{*}{ Year } & \multicolumn{5}{|c|}{ China } & \multicolumn{5}{|c|}{ Russia } \\
\hline & Savings & $\begin{array}{c}\text { Invest- } \\
\text { ment }\end{array}$ & $\begin{array}{l}\text { Net } \\
\text { private } \\
\text { Capital } \\
\text { Flows } \\
\end{array}$ & $\begin{array}{l}\text { Net } \\
\text { FDI } \\
\end{array}$ & $\begin{array}{c}\text { Capital } \\
\text { Flight }\end{array}$ & Savings & $\begin{array}{c}\text { Invest- } \\
\text { ment }\end{array}$ & $\begin{array}{c}\text { Net } \\
\text { private } \\
\text { Capital } \\
\text { flows } \\
\end{array}$ & $\begin{array}{l}\text { Net } \\
\text { FDI } \\
\end{array}$ & $\begin{array}{c}\text { Capital } \\
\text { Flight }\end{array}$ \\
\hline 1988 & 37 & 38 & & 1.0 & 5.6 & & & & & \\
\hline 1989 & 36 & 36 & & 1.0 & 6.1 & & & & & \\
\hline 1990 & 43 & 39 & 2.3 & 1.0 & 10.8 & & & & & \\
\hline 1991 & 39 & 36 & 2.0 & 1.2 & 10.9 & 40 & 39 & * & 0 & \\
\hline 1992 & na & na & 5.1 & 2.7 & 15.1 & 37 & 32 & 2.5 & 0 & $\begin{array}{c}3.3 \\
(5.7)\end{array}$ \\
\hline 1993 & 40 & 41 & 9.2 & 6.4 & 13.0 & 32 & 26 & 0.8 & 0.2 & $\begin{array}{c}2.7 \\
(5.7)\end{array}$ \\
\hline 1994 & 44 & 42 & 8.2 & 6.3 & 12.2 & 29 & 27 & 0.1 & 0.2 & 3.5 \\
\hline 1995 & 42 & 40 & 6.5 & 5.2 & & 26 & 25 & 0.3 & 0.6 & 2.2 \\
\hline
\end{tabular}

* less than 0.1 percent.

Notes:

1. Savings and investment figures are percentages of GDP, all in domestic currencies; foreign capital flows and capital flight are percentages of GNP converted into US dollars.

2. The capital flight figures for China are calculated using Gunter's (1996) high, adjusted residual estimates.

3. For Russia, the lower figures are Illarianov's estimates (Loukine, 1997) and the higher figures in parentheses are Sarafanov's (1995).

Sources:

Savings and investment shares: World Development Report, various issues.

Net private capital flows and net FDI: The numerators are taken from tables 1 and 3 . GNP is from World Bank (1997b), pp. 152, 440.

Capital flight: Table 2, Loukine (1997), and Sarafanov (1995). GNP statistics used as the divisor are from World Bank (1997b), pp. 152, 440. 